\title{
Editorial
}

\section{Outsourcing in Financial Services}

The regulation and supervision of financial firms governs both the direct and indirect processes connected to regulated activities so that the financial product is sold appropriately by the regulated firm to, inter alia, investors or depositors. The regulated activity an entity is authorised to undertake can be dismantled into various business processes such as distribution or marketing, which could be then undertaken by a third unregulated party. The regulated firm may seek to outsource certain business processes to an unregulated third party in order to achieve its business objectives of enhancing efficiency and reduce costs by transferring these parts to those that can undertake them more economically, regardless of where they are located. The outsourcing of these activities to a third party means that those regulated to undertake them have transferred responsibility for them to an unregulated entity that may not appreciate the importance of regulation in the way it performs those activities on behalf of the regulated firm.

The recent publication by the Joint Forum on Outsourcing of Financial Services $^{1}$ highlights the importance for regulators to monitor the use of unregulated third parties by financial firms. The work by the Joint Forum in devising the principles governing outsourcing are the result of consultation with a number of bodies, namely the Committee of the European Banking Supervisors. The publication highlights the risks posed by not monitoring the activities of third parties that undertake parts of regulated activities on behalf of regulated firms. It is estimated that in the USA alone $\$ 356 \mathrm{bn}$ of the financial services industry, which is 15 per cent of the sector, will be outsourced over the next five years. ${ }^{2}$ The growth in outsourcing is to increase the efficiency and reduce the cost of certain activities undertaken by the regulated entity to provide authorised activities. In a number of instances, activities are being transferred to another jurisdiction, for instance India is a popular country for processing transactions. The popularity of outsourcing brings to the fore the importance for a regulator to make sure regulated firms have in place appropriate systems and controls to ensure the third party complies with the rules and procedures a regulated entity would be required to do. While a number of regulators have policies in place to regulate outsourcing some form of international standards are considered necessary to highlight the risks posed by outsourcing. ${ }^{3}$ For example, the Annex to the Principles highlights the problems that may ensue from outsourcing, such as the third party not complying with the criteria to assess prospective borrowers for loans ultimately provided by a bank giving rise to the risk of mis-selling loans. The regulator in this case highlighted the fact that the bank did not have the procedures in place to check the loans granted by the third party. ${ }^{4}$ The Joint Forum has considered it important for the purposes of consistency to provide several principles as benchmarks to manage the relationship between the regulated entity, the regula- 
tors, and the third party. This is in the light of the fact that outsourcing is growing ever more popular so it is considered necessary to reduce the risks in order to retain the benefits it could provide for a regulated firm.

The Joint Forum provides a broad definition of outsourcing capturing the use of third parties or affiliates to undertake activities on a continuing basis that should be undertaken by the regulated firm. The types of activities that can be outsourced are, among others, information technology, back office operations and call centres that undertake contract functions. The outsourced functions may be situated outside the jurisdiction the regulated firm is authorised to undertake regulated activities, so that in itself poses certain risks, namely country risk.

The principles devised by the Joint Forum are considered necessary to mitigate the following risks associated with outsourcing: strategic risk, reputation risk, compliance risk, operational risk, exit strategy risk, counterparty risk, country risk, contractual risk, access risk, and concentration and systemic risk. ${ }^{5}$ In terms of strategic risk, this emanates from the fact that a third party may undertake activities not commensurate with the regulated firm's strategic goals that it sets to govern the business it undertakes. The use of a third party may pose a risk to a regulated firm's reputation by damaging customer relations by not adhering to the standards required by the jurisdiction where the regulated entity is located. The outsourcing of certain activities to offshore centres can result in access risk to information consequently impeding the timeliness of the information to regulators. The counterparty risk could arise by a third party not complying with the appropriate assessment criteria for providing credit for example. The Joint Forum placed particular emphasis on the regulator to monitor the potential systemic risk to the macroeconomic environment when the outsourcing is concentrated in the hands of few providers.

The principles devised by the Joint Forum first of all cover the relationship between the regulated and the third party by providing the policy of outsourcing needs to be appropriately assessed as to its feasibility by the board of directors and formalised in a transparent manner. This requires the regulated firm to have in place an appropriate risk management programme encompassing the third party's activities. The regulated firm is given responsibility for ensuring that the outsourcing does not hinder the supervision of the regulated activities by the regulator. It requires the regulated firm to conduct due diligence when selecting a third party service provider. The regulated firm would also be required to have in place effective contingency plans to mitigate the risks of any disaster affecting its business. The regulated firm is also required to ensure the confidentiality of the information in the hands of a third party provider. Finally the remaining three principles cover the regulators' responsibilities: the regulator is required to ensure that its ongoing supervision of the firm encompasses the outsourced activities. It also requires the regulator to ensure that the outsourcing does not hinder the regulated firm's ability to comply with its regulatory responsibilities. Finally, the regulator is required to monitor the risk posed by an over-concentration of outsourced services located within a small number of third party providers.

The Joint Forum have put in place guiding principles to highlight the problems of not monitoring outsourcing effectively whether that is at the firm or regulator level, thus undermining the potential benefits of outsourcing in terms of efficiency gains or reducing costs. The principles devised by the Joint Forum clearly place 
responsibility for managing outsourcing squarely on the shoulders of the regulated firm and its board of directors and senior management. The principles clearly provide that the outsourcing of financial services needs to be monitored on a continuous basis. Ultimately, it is for the regulators to ensure that those regulated comply with the measures they see fit to implement in this area to ensure the integrity of the financial markets and protect, inter alia, investors' and depositors' interests.

\section{References}

(1) Basel Committee on Banking Supervision (2005) The Joint Forum: Outsourcing in Financial Services, February.

(2) Ibid., p. 4.

(3) Ibid., p. 9.

(4) Ibid., Annex A.

(5) Ibid., p. 11.
Dr Dalvinder Singh

Senior Lecturer in Law Oxford Brookes University

IALS Editor 